\title{
Pengaruh Model Pembelajaran Tutor Sebaya terhadap Kemampuan Analitis Matematis dan Pemecahan Masalah Mahasiswa
}

\author{
Dwi Nurmalasari $^{1 *}$, Bambang Sri Anggoro ${ }^{2}$, \& Siska Andriani $^{3}$ \\ ${ }^{1,2,3}$ Universitas Islam Negeri Raden Intan Lampung, Bandar Lampung, Indonesia
}

\section{INFO ARTICLES}

Article History:

Received: 20-08-2021

Revised: 17-12-2021

Approved: 27-12-2021

Publish Online: $31-12-2021$

\section{Key Words:}

Peer Tutor Learning Model; Mathematical Analytical Ability; Problem Solving;

\begin{abstract}
This study aims to determine the effect of peer tutoring learning model on mathematical analytical skills and problem solving. This research is a Quasi Experimental Design Research with a $2 \times 2$ factorial research design. The samples in this study were students of the 4th semester of mathematics education in class D and class E at UIN Raden Intan Lampung. The sampling technique used is a class random technique. Data collection techniques in this study are tests, interviews and observations. Normality test was conducted before testing the research hypothesis. Hypothesis testing in this study used the Multivariate Analysis of Variance (Manova) test. The result of hypothesis testing obtained a significance of $<0.05$ which indicates that there is an influence on mathematical analytical abilities and problem solving abilities given the peer tutor learning model than conventional learning. Therefore, there is an influence of peer tutor learning model on mathematical analytical ability and problem solving ability ofstudent UIN Raden Intan Lampung.
\end{abstract}

\begin{abstract}
Abstrak: Penelitian bertujuan untuk mengetahui pengaruh model pembelajaran tutor sebaya terhadap kemampuan analitis matematis dan pemecahan masalah. Penelitian ini merupakan jenis penelitian Quasi Experiment Design dengan rancangan penelitian faktorial $2 \times 2$. Sampel dalam penelitian ini adalah Mahasiwa Jurusan Pendidikan Matematika semester 4 kelas D dan kelas E UIN Raden Intan Lampung. Teknik pengambilan sampel yang digunakan adalah teknik acak kelas. Teknik pengumpulan data dalam penelitian ini yaitu tes, wawancara dan observasi. Uji normalitas dilakukan sebelum uji hipotesis penelitian. Pengujian hipotesis dalam penelitian ini menggunakan Multivariate Analysis of Variance (Manova). Hasil pengujian hipotesis diperoleh signifikansi $<0.05$ yang menunjukan bahwa terdapat pengaruh pada kemampuan analitis matematis dan kemampuan pemecahan masalah yang diberikan model pembelajaran tutor sebaya daripada pembelajaran konvensional. Oleh karena itu, terdapat pengaruh model pembelajaran tutor sebaya terhadap kemampuan analitis matematis dan kemampuan pemecahan masalah pada mahasiswa UIN Raden Intan Lampung.
\end{abstract}

Correspondence Address: Jl. Letnan Kolonel H Endro Suratmin, Sukarame, Bandar Lampung, Indonesia, Kode Pos 35131; e-mail: dwinurmalasari20@gmail.com

How to Cite (APA 6 ${ }^{\text {th }}$ Style): Nurmalasari, D., Anggoro, B.S., \& Andriani, S. (2021). Pengaruh Model Pembelajaran Tutor Sebaya terhadap Kemampuan Analitis Matematis dan Pemecahan Masalah Mahasiswa. JKPM (Jurnal Kajian Pendidikan Matematika), 7(1): 95-106. http://dx.doi.org/10.30998/jkpm.v7i1.10453

Copyright: 2021 Dwi Nurmalasari, Bambang Sri Anggoro, Siska Andriani

Competing Interests Disclosures: The authors declare that they have no significant competing financial, professional or personal interests that might have influenced the performance or presentation of the work described in this manuscript. 


\section{PENDAHULUAN}

Matematika analisis merupakan salah satu cabang dari analisis matematika yang berhubungan dengan himpunan bilangan real dan fungsi real variabel. Matakuliah matematika analisis merupakan matakuliah wajib yang harus diambil untuk mahasiswa jurusan pendidikan matematika di Fakultas Tarbiyah dan Keguruan Universitas Islam Negeri Raden Intan Lampung. Tujuan diberikannya matakuliah matematika analisis merupakan alat untuk melatih mahasiswa berpikir logis atau melakukan penalaran yang tepat. Matakuliah matematika analisis secara umum mengaplikasikan konsep matematis yang bernalar secara analisis dan berpikir secara sistematis.

Pada pembelajaran matematika analisis ditemukan mahasiswa yang kurang aktif dalam berinteraksi pada proses pembelajaran di kelas, baik antara mahasiswa dengan dosen maupun antara mahasiswa dengan mahasiswa lainnya. Kebanyakan mahasiswa menunggu apa yang disampaikan oleh dosen, mencatat definisi, pembuktian teorema, akibat, lemma dan penyelesaian soal jika telah selesai ditulis dan dijelaskan oleh dosen di papan tulis. Hal tersebut dikuatkan penelitian Mulyatna \& Nofiansyah (2019), kondisi bahwa mahasiswa baru sebatas menirukan langkah-langkah yang diberikan dosen dan akan kesulitan mengembangkan dalam notasi dan simbol-simbol yang berbeda. Mahasiswa tidak suka membaca dan mempelajari buku referensi dan mendiskusikan pembuktian teorema sebelum perkuliahan karena mengandalkan informasi searah dari pembelajaran konvensional oleh dosen. Sudarman \& Vahlia (2016) bahkan memberikan adanya permasalahan kurang fokusnya mahasiswa dalam belajar saat dosen menjelaskan. Hal ini menunjukkan peran penting kondisi pembelajaran dalam meningkatkan kemampuan berpikir mahasiswa. Terlebih kemampuan yang dilihat adalah kemampuan analitis matematis. Mahasiswa di samping faktor penyampai materi, tetapi ada faktor suasana perkuliahan yang dapat mendukung peningkatan kemampuan analitis matematis. Hal ini sejalan dengan penelitian Fatma (2016) yang menyimpulkan bahwa kemampuan analitis matematis mahasiswa yang diajarkan dengan menggunakan model pembelajaran yang tepat, lebih tinggi daripada mahasiswa yang diajarkan dengan pembelajaran konvensional. Hal ini dibuktikkan dengan tingkat pencapaian penilaian kemampuan analitis matematis mahasiswa lebih baih baik pada mahasiswa yang diajarkan dengan model pembelajaran group investigation.

Dalam penelitian Ilma, et. al. (2017), lebih ditekankan lagi bahwa setelah tingkatan pemahaman, penerapan, dan mengingat bahwa berpikir analisis berada pada tingkatan tertinggi. Dengan demikian kemampuan analitis matematis merupakan kemampuan untuk menguraikan, meneliti dan menganalisis berbagai informasi yang digunakan untuk mengetahui suatu pengetahuan ilmu dengan menggunakan pikiran yang logis. Kemampuan analitis matematis merupakan suatu kemampuan berpikir tingkat tinggi yang harus dimiliki oleh siswa ataupun mahasiswa. Kemampuan analitis ini tidak bisa dicapai oleh mahasiswa jika mahasiswa belum menguasai aspek-aspek kognitif sebelumnya. Kemampuan analitis ini sangat komplek yang di dalamnya terdapat aspek pengetahuan, pemahaman dan aplikasi.

Suherman \& Sukjaya (1990) mengungkapkan bahwa kemampuan analisis merupakan kemampuan untuk merinci atau menguraikan suatu masalah (soal yang diberikan) menjadi bagianbagian yang lebih kecil serta dapat memahami hubungan di antara bagian-bagiannya. Hal yang sangat mendasar merujuk penelitian Desti, et. al. (2018), mahasiswa yang belum dapat menguasai konsep yang mendasar maka jelas akan kesulitan menguasai konsep yang lebih lanjut. Seperti yang disampaikan Ilma, et. al. (2017) berpikir analisis berada pada tingkatan tertinggi, maka sudah semestinya menekankan pada pemecahan materi ke dalam bagian-bagian yang lebih spesifik atau kecil dan menyelidiki hubungan-hubungan dan bagian-bagian tersebut kemudian bagian-bagian tersebut diorganisir. Kemampuan analisis merupakan suatu proses pengoperasian dalam otak yang mampu menghasilkan pengetahuan berupa mengasah data, membedakan fenomena, membuat kesimpulan, meramalkan peristiwa, merinci, menguraikan, mencari hubungan, serta mengevaluasi kesimpulan umum berdasarkan penyelidikan. 
Pendapat tersebut sejalan dengan pendapat Bloom (1985) menyatakan bahwa kemampuan analisis merupakan suatu proses memecahkan masalah atau gagasan menjadi bagian-bagian, menguji setiap bagian untyk melihat bagaimana bagian tersebut saling cocok dengan yan lainnya, atau terkait satu sama lainnya, bagaimana komponen tersebut itu berhubungan dan terorganisasaikan, membedakan fakta dari hayalan, serta mengeksplorasikan bagaimana bagian-bagian tersebut dikombinasikan kembali dugaan cara-cara baru.

Untuk mengukur kemampuan analisis mahasiswa diperlukan indikator sebagai tolak ukurnya. Mengacu pada pemikiran Krathwohl (2002), beberapa indikator kemampuan analisis matematis antara lain, (1) memberikan alasan mengapa sebuah jawaban suatu masalah masuk akal; (2) membuat dan mengevaluasi kesimpulan umum berdasarkan penelitian; (3) meramalkan atau menggambarkan kesimpulan dari informasi yang akurat; (4) mempertimbangkan validitas dari pernyataan dengan menggunakan pikiran deduktif dan induktif; (5) menggunakan data yang mendukung untuk menerangkan mengapa langkah yang digunakan dalam jawaban adalah benar; (6) menganalisis informasi yang masuk dan membagi-bagi atau terorganisirkan informasi ke dalam bagian yang lebih kecil lagi untuk mengenali hubungannya; (7) dapat mengenali serta membedakan faktor penyebab dan akibat dari semua skenario yang sulit; dan (8) mengidentifikasi atau merumuskan pertanyaan.

Sementara itu, mengacu pada Fajriah \& Suseno (2014), suatu kemampuan kognitif yang menjadi tujuan dari pendidikan sekolah, salah satu di dalamnya merupakan kemampuan pemecahan. Penelitian Kusmaharti \& Yustitia (2020), dapat dijadikan acuan bahwa suatu proses belajar individu untuk merespon dan mencari jalan ketika suatu jawaban dan langkah-langkah belum sempurna membutuhkan kemampuan pemecahan masalah. Dengan demikian, individu yang hanya sebatas memiliki kemampuan untuk menirukan, dalam artian menemukan solusi matematika yang setipe, maka akan kesulitan jika dihadapkan pada persoalan dengan solusi yang langkahnya berbeda. Belum lagi kalua konsep yang diberikan sudah diberikan variasi dengan dikaitkan pada materi lainnya. Sejalan dengan Iswara \& Sundayana (2021), mengaitkan materi yang telah lampau (pengalaman belajar sebelumnya) dengan kondisi baru (konsep yang sedang dipelajari maupun belum dipelajari) merupakan proses menerapkan pembelajaran matematika dengan kaidah pemecahan masalah.

Kendala yang dihadapai terkait pemecahan masalah, sangat memungkinkan belum mampu mengaitkan antar konsep, baik itu yang telah dipelajari, yang sedang dipelajari, maupun belum dipelajari. Dengan demikian, adanya tutor sebaya memungkinkan saling bertukar pikiran, saling memberikan penguatan terkait materi-materi yang sedang dipecahkan. Nasution \& Oktaviani (2020) dalam penelitiannya juga dapat dijadikan rujukan bahwa modal pengetahuan (konsep yang telah diterima sebelumnya) dapat membantu pengelolaan masalah matematika sehingga diperoleh solusi yang tepat.

Menurut Polya, dalam inti penelitian Setiawan, et. al. (2021), Nurhalin \& Ramlah (2021), Syadid \& Sutiarso (2021), Safi'i \& Bharata (2021) pemecahan masalah adalah usaha menemukan jalan keluar dari suatu tujuan yang sulit segera dicapai. Jadi kemampuan pemecahan masalah adalah kemampuan kognitif untuk mencari suatu penyelesaian atau jalan keluar sehingga menghasilkan suatu tujuan yang hendak dicapai. Ada bebarapa indikator dari kemampuan pemecahan masalah, indikator tahap kemampuan pemecahan masalah menurut Polya yang diadobsi dari penelitianpenelitian Setiawan, et. al. (2021), Nurhalin \& Ramlah (2021), Syadid \& Sutiarso (2021), Safi'i \& Bharata (2021) antara lain, (1) memahami masalah; (2) membuat rencana pemecahan masalah; (3) menyelesaikan rencana pemecahan masalah; (4) memeriksa kembali hasilnya.

Berdasarkan hasil observasi yang telah dilakukan penulis pada mahasiswa UIN Raden Intan Lampung Fakultas Tarbiyah dan Keguruan Pendidikan Matematika semester 4 indikasi awal menunjukkan kemampuan analitis matematis dan kemampuan pemecahan masalah yang kurang optimal disebabkan oleh ketidaktepatan model pembelajaran yang digunakan oleh dosen dalam pembelajaran matakuliah matematika analisis. Hal ini terlihat pada saat pengamatan proses pembelajaran berlangsung, mahasiswa cenderung pasif dalam mengikuti pembelajaran, begitupun dengan soal-soal yang diberikan kepada mahasiswa hanya berupa pertanyaan pada level pemahaman 
(low order thinking skills), sehingga kemampuan analitis matematis dan kemampuan pemecahan masalah mahasiswa tidak berkembang dengan baik. Berikut ini disajikan dalam Tabel 1., hasil tes mahasiswa UIN Raden Intan Lampung Fakultas Tarbiyah dan Keguruan Pendidikan Matematika semester 4, pada studi pendahuluan.

Tabel 1. Data Hasil Tes Kemampuan Analitis Matematis dan Kemampuan Pemecahan Masalah

\begin{tabular}{lccccccccc}
\hline \multirow{2}{*}{ No. } & \multirow{2}{*}{ Kelas } & A & B + & B & C+ & C & D & E & \multirow{2}{*}{ Jumlah } \\
\hline 1. & A & 1 & 4 & 8 & 5 & 5 & 2 & 6 & 31 \\
2. & B & 4 & 5 & 8 & 3 & 4 & 2 & 12 & 38 \\
3. & C & 2 & 7 & 4 & 6 & 6 & 4 & 5 & 34 \\
\multicolumn{2}{l}{ Jumlah } & 7 & 16 & 20 & 14 & 15 & 8 & 23 & 103 \\
\hline
\end{tabular}

Sumber: data studi pendahuluan, 2021

Hal tersebut didukung hasil penelitian Căprioară (2015) menunjukkan bahwa proses pembelajaran di kelas juga bergantung pada model pembelajaran yang berbeda yang dapat mempengaruhi kemampuan pemecahan masalah peserta didik. Sejalan dengan hasil penelitian Yavuz \& Erbay (2015), menunjukkan bahwa guru memiliki peran dalam upaya peningkatan kemampuan pemecahan masalah peserta didik. Demikian pula Zahrawati (2020), menekankan bahwa pengajaran yang baik seyogyanya melibatkan hubungan komunikasi yang berinteraksi antara individu. Oleh karena itu, penulis mencoba untuk menyajikan sebuah model pembelajaran yang disebut model pembelajaran tutor sebaya. Hal ini sesuai dengan penelitian Nofitasari, et. al. (2015), menunjukkan bahwa kemampuan pemecahan masalah peserta didik dengan model pembelajaran tutor sebaya bernuansa etnomatematika lebih baik dibandingkan degan menggunakan pembelajaran konvensional.

Model pembelajaran tutor sebaya merupakan salah satu alternatif cara yang dapat diaplikasikan kepada peserta didik dalam proses pembelajaran. Tutor sebaya adalah suatu model pembelajaran yang kooperatif dimana rasa saling mengahrgai dan mengerti dilatih diantara peserta didik yang bekerjasama. Tutor sebaya ini memudahkan mahasiswa berpatisipasi aktif serta dapat memecahkan masalah bersama-sama, sehingga tujuan pemahaman terhadap materi pembelajaran yang diberikan dapat tercapai. Model pembelajaran tutor sebaya adalah model pembelajaran yang dilakukan oleh teman atau kakak kelas, atau yang memiliki usia sama atau sebaya. Tutor sebaya dapat melatih serta mengembangkan kemampuan, nilai kemanusiaan, peserta didik lebih percaya diri, menghargai pendapat orang lain serta saling menerima kekurangan teman teman. Pendidik yang menggunakan model pembelajaran tutor sebaya mengarah kepada belajar kelompok, menyajikan informasi baru kepada peserta didik setiap kali pertemuan. Peserta didik dibagi atas beberapa kelompok yang terdiri atas beberapa 4-5 peserta didik yang berasal dari berbagai macam yang memiliki kemampuan kecerdasan normal dan lemah. Tutor sebaya hendaknya memiliki nilai di atas rata-rata teman sebayanya sehingga dapat memberikan penjelasan kepada peserta didik lainnya yang mengalami masalah dalam menyelesaikan permasalahan soal serta memilki kesabaran dan motivasi belajar lebih tinggi.

Berdasarkan permasalahan tersebut, maka perlu dilakukan suatu penelitian tentang pengaruh model pembelajaran tutor sebaya terhadap kemampuan analitis matematis dan kemampuan pemecahan masalah mahasiswa. Tujuan penelitian ini untuk mengetahui pengaruh model pembelajaran tutor sebaya terhadap kemampuan analitis matematis dan kemampuan pemecahan masalah mahasiswa pada perkuliahan matematika analisis.

\section{METODE}

Jenis penelitian ini merupakan penelitian kuantitatif dengan pendekatan penelitian Quasi Exsperimental Design, yaitu desain yang mempunyai kelompok kontrol tetapi tidak berfungsi 
sepenuhnya untuk mengontrol variabel-variabel luar yang mempengaruhi pelaksanan penelitian. esain penelitian ini menggunakan desain penelitian "Posttest Only Control Design". Penelitian ini dilaksanakan pada semester genap tahun ajaran 2020/2021 di Program Studi Pendidikan Matematika Fakultas Tarbiyah Dan Keguruan UIN Raden Intan Lampung. Populasi pada penelitian ini adalah mahasiswa semester IV sebanyak 4 kelas sedangkan sampel dari penelitian ini adalah sebanyak 2 kelas yaitu kelas D dan E. Pengambilan sampel dipilih dua lokal yaitu lokal D dan E dengan menggunakan teknik acak kelas, teknik ini dilakukan oleh peneliti dengan cara mengundi. Adapun desain penelitian yang digunakan dalam penelitian ini berbentuk faktorial $2 \times 2$ yang dipaparkan pada Tabel 2..

Tabel 2. Desain Penelitian

\begin{tabular}{|c|c|c|}
\hline Kemampuan (Y) & $\begin{array}{l}\text { Model Pembelajaran Tutor } \\
\text { Sebaya }\left(X_{1}\right)\end{array}$ & $\begin{array}{l}\text { Model Pembelajaran } E \text { - } \\
\text { Learning }\left(X_{2}\right)\end{array}$ \\
\hline $\begin{array}{l}\text { Kemampuan Analitis } \\
\text { Matematis }\left(Y_{1}\right)\end{array}$ & $X_{1} Y_{1}$ & $X_{2} Y_{1}$ \\
\hline $\begin{array}{c}\text { Kemampuan Pemecahan } \\
\text { Masalah }\left(Y_{2}\right)\end{array}$ & $X_{1} Y_{2}$ & $X_{2} Y_{2}$ \\
\hline
\end{tabular}

Adapun teknik pengumpulan data pada penelitian ini yaitu tes, observasi, dan wawancara. Untuk mengukur kemampuan analitis matematis dan kemampuan pemecahan masalah mahasiswa pada penelitian ini menggunakan tes berbentuk uraian dengan cara memberikannya pada kedua kelas sampel setelah diberi perlakuan. Pada penelitian ini, penulis menggunakan instrumen tes berupa tes essay, yang sebelum diberikan kepada mahasiswa dilakukan uji validitas, reliabilitas, tingkat kesukaran serta uji daya beda. Teknik wawancara digunakan sebagai teknik pengumpulan data dengan cara berdialog kepada seseorang untuk menggali informasi. Data pada penelitian ini berupa data hasil tes soal kemampuan analitis matematis dan kemampuan pemecahan masalah mahasiswa.

Teknik analisis data pada penelitian ini menggunakan uji prasyarat (uji normalitas dan uji homogenitas dan uji hipotesis (uji manova). Instrumen pada penelitian menggunakan 8 soal tes kemampuan analitis matematis dan 4 soal tes kemampuan pemecahan masalah.

Analisis data pada penelitian ini menggunakan uji prasyarat dan uji hipotesis. Uji prasyarat meliputi, uji normalitas dan uji homogenitas. Uji normalitas untuk mengetahui apakah data berdistribusi normal atau tidak. Pada uji normalitas ini, menggunakan bantuan program SPSS 22 dengan taraf signifikan 5\%. Syarat uji manova adalah dengan terpenuhinya data berdistribusi normal dengan kriteria uji Kolmogorof Smirnov berdasarkan acuan dalam Tabel 3..

Tabel 3. Kriteria Kolmogorof Smirnov

\begin{tabular}{ccc}
\hline Probabilitas & Keterangan & Kesimpulan \\
\hline$p-$ value $\geq 0,05$ & $H_{0}$ diterima & Berdistribusi Normal \\
$p-$ value $<0,05$ & $H_{1}$ diterima & Tidak Berdistribusi Normal \\
\hline
\end{tabular}

Sedangkan uji homogenitas untuk mengetahui apakah data yang diteliti homogen atau tidak. Pada penelitian ini menggunakan bantuan program SPSS 22 dengan taraf signifikan 5\%. Syarat uji manova adalah dengan terpenuhinya data berdistribusi homogen mengacu pada Tabel 4. dengan kriteria uji homogeneity of varians. 
Tabel 4. Kriteria Uji Homogeneity of Varians

\begin{tabular}{ccc}
\hline Probabilitas & Keterangan & Kesimpulan \\
\hline$p-$ value $\geq 0,05$ & $H_{0}$ diterima & Homogen \\
$p-$ value $<0,05$ & $H_{1}$ diterima & Tidak homogen \\
\hline
\end{tabular}

Uji hipotesis Manova (Multivariate Analysis of Variance) adalah suatu teknik statistik yang digunakan untuk menghitung pengujian signifikansi perbedaan rata-rata secara bersamaan antara kelompok dengan dua variabel terikat atau lebih. Manova merupakan teknik analisis statistik yang digunakan untuk menguji kesamaan nilai tengah beberapa variabel dari beberapa banyak populasi. Uji Manova ini menggunakan bantuan program SPSS 22 dengan taraf signifikan 5\%, jika $p-$ value $\geq 0,05$ maka $H_{0}$ diterima sedangkan $p$-value $<0,05$ maka $H_{0}$ ditolak, sehingga terdapat pengaruh.

\section{HASIL}

Penelitian ini bertujuan untuk mengetahui pengaruh model pembelajaran tutor sebaya terhadap kemampuan analitis matematis dan pemecahan masalah mahasiswa dan selanjutnya diuji dengan analisis Manova. Berdasarkan hasil perhitungan data deskriptif yang diperoleh kelas yang menggunakan model pembelajaran tutor sebaya dan kelas yang menggunakan metode pembelajaran konvensional untuk kemampuan komunikasi matematika dan kemampuan pemecahan masalah matematika disajikan pada Tabel 5.

Tabel 5. Deskripsi Data Amatan Post-Test Kemampuan Analitis Matematis dan Kemampuan Pemecahan Masalah

\begin{tabular}{|c|c|c|c|c|c|c|c|}
\hline \multirow[t]{2}{*}{ Kelompok } & \multirow{2}{*}{$X_{\text {maks }}$} & \multirow{2}{*}{$X_{\min }$} & \multicolumn{3}{|c|}{ Ukuran Tendensi } & \multicolumn{2}{|c|}{$\begin{array}{c}\text { Ukuran Variansi } \\
\text { Kelompok }\end{array}$} \\
\hline & & & $\bar{x}$ & $M_{e}$ & $M_{O}$ & $R$ & $S_{d}$ \\
\hline \multicolumn{8}{|c|}{ Kemampuan Analitis Matematis } \\
\hline Eksperimen & 95,00 & 65,75 & 80,22 & 80,50 & 90,00 & 29,25 & 8,23 \\
\hline Kontrol & 88,00 & 37,00 & 67,63 & 69,25 & 65,00 & 51,00 & 11,15 \\
\hline \multicolumn{8}{|c|}{ Kemampuan Pemecahan Masalah } \\
\hline Eksperimen & 90,50 & 65,25 & 79,26 & 80,75 & 70,00 & 25,25 & 6,99 \\
\hline Kontrol & 85,00 & 40,00 & 59,69 & 60,12 & 50,00 & 45,00 & 11,14 \\
\hline
\end{tabular}

Sumber: diolah dari data penelitian, 2021

Hasil post-test kemampuan analitis matematis kelas eksperimen didapatkan nilai maksimum dan minimum masing-masing sebesar 95,00 dan 65,75, sedangkan pada kelas kontrol nilai maksimum dan minimum masing-masing sebesar 88,00 dan 37,00. Kemudian rata-rata nilai, median dan modus pada kelas eksperimen masing-masing sebesar $(80,22),(80,50)$ dan $(90,00)$, sedangkan pada kelas kontrol rata-rata nilai, median dan modus masing-masing sebesar $(67,63),(69,25)$ dan $(65,00)$.

Hasil post-test kemampuan pemecahan masalah kelas eksperimen didapatkan nilai maksimum dan minimum sebesar 90,50 dan 65,25, sedangkan pada kelas kontrol didapatkan nilai maksimum dan minimum masing masing sebesar 85,00 dan 40,00. Kemudian rata-rata nilai, median dan modus pada kelas eksperimen masing-masing sebesar $(79,26),(80,75)$ dan $(70,00)$, sedangkan pada kelas kontrol rata-rata nilai, median dan modus masing-masing sebesar $(59,69),(60,12)$ dan $(50,00)$.

Pengolahan data dilanjutkan dengan uji analisis data yang meliputi uji normalitas dan uji homogenitas. Dilakukan analisis data dan dari perhitungan hasil tes yang telah dilakukan, diperoleh hasil uji normalitas yang menunjukkan bahwa sampel berasal dari populasi yang berdistribusi normal, hal ini terlihat dari perhitungan di kelas eksperimen di peroleh hasil $p$-value $=0,128$ dengan taraf signifikan 5\% dan pada kelas kontrol di peroleh hasil $p-$ value $=0,178$ dengan taraf signifikan 5\%. Karena data berasal dari populasi yang berdistribusi normal, Sehingga dapat dilanjutkan dengan uji homogenitas. Berdasarkan hasil homogenitas pada kelas eksperimen $p-$ 
value $=0,132$ dengan taraf signifikan 5\% dan pada kelas kontrol diperoleh hasil $p-$ value $=$ 0,132 dengan taraf signifikan 5\%. Sehingga dapat disimpulkan bahwa kedua kelas yaitu kelas D dan E mempunyai varians yang sama (homogen).

Berdasarkan hasil pengujian hipotesis menggunakan Manova (Multivariate Analysis of Variance) dengan uji pertama yaitu uji pengaruh antar subjek/variabel (Test of Between-Subject Effects). Hasil ujinya dirangkum pada Tabel 6.

Berdasarkan Tabel 6., pada kemampuan analitis matematis diperoleh hasil $p$-value 0,000 dengan derajat angka signifikasi 5\%. Hal tersebut menunjukkan bahwa $p-$ value $<0,05$, sehingga $H_{O A}$ ditolak dan $H_{1 A}$ diterima. Kesimpulannya yaitu terdapat pengaruh model pembelajaran tutor sebaya terhadap kemampuan analitis matematis mahasiswa.

Tabel 6. Uji Pengaruh Antar Subjek

\begin{tabular}{|c|c|c|c|c|c|c|c|c|c|}
\hline Source & Dependent Variable & $\begin{array}{l}\text { Type III } \\
\text { Sum of } \\
\text { Squares }\end{array}$ & $\mathrm{df}$ & $\begin{array}{l}\text { Mean } \\
\text { Square }\end{array}$ & $\mathrm{F}$ & Sig. & $\begin{array}{c}\text { Partial } \\
\text { Eta } \\
\text { Squared }\end{array}$ & $\begin{array}{l}\text { Noncent. } \\
\text { Parameter }\end{array}$ & $\begin{array}{c}\text { Observed } \\
\text { Power }\end{array}$ \\
\hline \multirow[t]{2}{*}{$\begin{array}{l}\text { Corrected } \\
\text { Model }\end{array}$} & $\begin{array}{l}\text { Kemampuan Analitis } \\
\text { Matematis }\end{array}$ & $2378.251^{a}$ & 1 & 2378.251 & 24.751 & .000 & .299 & 24.751 & .998 \\
\hline & $\begin{array}{l}\text { Kemampuan } \\
\text { Pemecahan Masalah }\end{array}$ & $5743.795^{b}$ & 1 & 5743.795 & 66.311 & .000 & .533 & 66.311 & 1.000 \\
\hline \multirow[t]{2}{*}{ Intercept } & $\begin{array}{l}\text { Kemampuan Analitis } \\
\text { Matematis }\end{array}$ & 327931.301 & 1 & 327931.301 & 3412.803 & .000 & .983 & 3412.803 & 1.000 \\
\hline & $\begin{array}{l}\text { Kemampuan } \\
\text { Pemecahan Masalah }\end{array}$ & 289669.068 & 1 & 289669.068 & 3344.150 & .000 & .983 & 3344.150 & 1.000 \\
\hline \multirow[t]{2}{*}{$X$} & $\begin{array}{l}\text { Kemampuan Analitis } \\
\text { Matematis }\end{array}$ & 2378.251 & 1 & 2378.251 & 24.751 & .000 & .299 & 24.751 & .998 \\
\hline & $\begin{array}{l}\text { Kemampuan } \\
\text { Pemecahan Masalah }\end{array}$ & 5743.795 & 1 & 5743.795 & 66.311 & .000 & .533 & 66.311 & 1.000 \\
\hline \multirow[t]{2}{*}{ Error } & $\begin{array}{l}\text { Kemampuan Analitis } \\
\text { Matematis }\end{array}$ & 5573.135 & 58 & 96.089 & & & & & \\
\hline & $\begin{array}{l}\text { Kemampuan } \\
\text { Pemecahan Masalah }\end{array}$ & 5023.939 & 58 & 86.620 & & & & & \\
\hline \multirow[t]{2}{*}{ Total } & $\begin{array}{l}\text { Kemampuan Analitis } \\
\text { Matematis }\end{array}$ & 335882.688 & 60 & & & & & & \\
\hline & $\begin{array}{l}\text { Kemampuan } \\
\text { Pemecahan Masalah }\end{array}$ & 300436.803 & 60 & & & & & & \\
\hline \multirow[t]{2}{*}{$\begin{array}{l}\text { Corrected } \\
\text { Total }\end{array}$} & $\begin{array}{l}\text { Kemampuan Analitis } \\
\text { Matematis }\end{array}$ & 7951.386 & 59 & & & & & & \\
\hline & $\begin{array}{l}\text { Kemampuan } \\
\text { Pemecahan Masalah }\end{array}$ & 10767.734 & 59 & & & & & & \\
\hline
\end{tabular}

a. R Squared $=.299$ (Adjusted R Squared $=.287$ )

b. R Squared $=.533$ (Adjusted R Squared $=.525$ )

c. Computed using alpha $=, 05$

Sumber: diolah dari data penelitian, 2021

Pada kemampuan pemecahan masalah diperoleh hasil $p$-value 0,000 dengan derajat angka signifikasi 5\%. Hal tersebut menunjukkan bahwa $p$-value $<0,05$, sehingga $H_{O B}$ ditolak dan $H_{1 B}$ diterima. Kesimpulannya yaitu terdapat pengaruh model pembelajaran tutor sebaya terhadap kemampuan pemecahan masalah mahasiswa

Kemudian dilakukan uji multivariat untuk melihat pengaruh model pembelajaran tutor sebaya terhadap kemampuan analitis matematis dan kemampuan pemecahan masalah mahasiswa. Uji multivariat ini menggunakan uji hasil analisis Wilks' Lamda, hasilnya dapat dilihat pada Tabel 7 .. 
Tabel 7. Uji Multivariat

\begin{tabular}{|c|c|c|c|c|c|c|c|c|c|}
\hline & Effect & Value & $\mathrm{F}$ & $\begin{array}{l}\text { Hypothes } \\
\text { is df }\end{array}$ & Error df & Sig. & $\begin{array}{l}\text { Partial } \\
\text { Eta } \\
\text { Squared }\end{array}$ & $\begin{array}{c}\text { Noncent. } \\
\text { Parameter }\end{array}$ & $\begin{array}{c}\text { Observed } \\
\text { Powerc }\end{array}$ \\
\hline \multirow[t]{3}{*}{ Intercept } & Pillai's Trace & .990 & $2864.204^{b}$ & 2.000 & 57.000 & .000 & .990 & 5728.407 & 1.000 \\
\hline & \multirow{2}{*}{$\begin{array}{l}\text { Wilks' Lambda } \\
\text { Hotelling's Trace } \\
\text { Roy's Largest } \\
\text { Root }\end{array}$} & $\begin{array}{r}.010 \\
100.498\end{array}$ & $\begin{array}{l}2864.204^{b} \\
2864.204^{b}\end{array}$ & $\begin{array}{l}2.000 \\
2.000\end{array}$ & $\begin{array}{l}57.000 \\
57.000\end{array}$ & $\begin{array}{l}.000 \\
.000\end{array}$ & $\begin{array}{l}.990 \\
.990\end{array}$ & $\begin{array}{l}5728.407 \\
5728.407\end{array}$ & $\begin{array}{l}1.000 \\
1.000\end{array}$ \\
\hline & & 100.498 & $2864.204^{b}$ & 2.000 & 57.000 & .000 & .990 & 5728.407 & 1.000 \\
\hline \multirow[t]{3}{*}{$x$} & Pillai's Trace & .580 & $39.405^{b}$ & 2.000 & 57.000 & .000 & .580 & 78.810 & 1.000 \\
\hline & \multirow{2}{*}{$\begin{array}{l}\text { Wilks' Lambda } \\
\text { Hotelling's Trace } \\
\text { Roy's Largest } \\
\text { Root }\end{array}$} & $\begin{array}{r}.420 \\
1.383\end{array}$ & $\begin{array}{l}39.405^{b} \\
39.405^{b}\end{array}$ & $\begin{array}{l}2.000 \\
2.000\end{array}$ & $\begin{array}{l}57.000 \\
57.000\end{array}$ & $\begin{array}{l}.000 \\
.000\end{array}$ & $\begin{array}{l}.580 \\
.580\end{array}$ & $\begin{array}{l}78.810 \\
78.810\end{array}$ & $\begin{array}{l}1.000 \\
1.000\end{array}$ \\
\hline & & 1.383 & $39.405^{b}$ & 2.000 & 57.000 & .000 & .580 & 78.810 & 1.000 \\
\hline
\end{tabular}

Sumber: diolah dari data penelitian, 2021

Berdasarkan Tabel 7., dapat dilihat bahwa diperoleh $p$-value sebesar 0,000 dan derajat angkat signifikasi 5\%. Hal ini menunjukkan bahwa $p$-value $<0,05$, sehingga $H_{O A B}$ ditolak dan $H_{1 A B}$ diterima. Kesimpulannya yaitu terdapat pengaruh model pembelajaran tutor sebaya terhadap kemampuan analitis matematis dan kemampuan pemecahan masalah mahasiswa.

\section{PEMBAHASAN}

Berdasar pada hasil uji statistik dengan Wilk's Lamda dapat disimpulkan bahwa terdapat perbedaan yang signifikan pada kemampuan analitis matematis dan kemampuan pemecahan masalah mahasiswa yang diajarkan dengan menggunakan model pembelajaran tutor sebaya daripada mahasiswa yang diajarkan menggunakan pembelajaran konvensional.

Adanya pengaruh ini disebabkan karena adanya penerapan model pembelajaran tutor sebaya dengan langkah pembelajaran yang menuntut mahasiswa untuk ikut aktif dalam kegiatan pembelajaran khususnya dalam mengasah kemampuan analitis matematis dan kemampuan pemecahan masalah sehingga memudahkan mahasiswa dalam memecahkan masalah. Hal ini sejalan dengan pendapat penelitian Fatma (2016) yang menyimpulkan bahwa kemampuan analitis matematis mahasiswa yang diajarkan dengan menggunakan model pembelajaran yang tepat, lebih tinggi daripada mahasiswa yang diajarkan dengan pembelajaran konvensional. Hal ini dibuktikan dengan tingkat pencapaian penilaian kemampuan analitis matematis mahasiswa lebih baih baik pada mahasiswa yang diajarkan dengan model pembelajaran group investigation.

Model pembelajaran sangat besar pengaruhnya dalam penguasaan kemampuan mahasiswa. Kemampuan belajar mahasiswa yang baik diperoleh dari proses belajar yang benar. Proses belajar yang benar adalah proses belajar yang melibatkan mahasiswa itu sendiri. Untuk itu dosen harus menggunakan model pembelajaran yang dapat melibatkan mahasiswa secara aktif dalam kegiatan belajar mengajar. Salah satu yang dapat menunjang hal tersebut adalah model pembelajaran tutor sebaya. Dalam pembelajaran matematika analisis berbagai model dapat digunakan untuk mencapai tujuan pembelajaran di kelas. Antar model memiliki kelebihan dan kekurangan dalam pelaksanaannya, namun dalam meningkatkan kemampuan matematika mahasiswa dapat diukur melalui tes uraian untuk mengetahui kompetensi dasar siswa dalam penguasaan atau kemampuan matematika analisis mahasiswa baik model pembelajaran tutor sebaya maupun model yang lainnya merupakan suatu cara dalam menyajikan (menguraikan, memberi contoh dan memberi latihan) untuk mencapai tujuan meningkatkan kemampuan yaitu kemampuan analitis matematis dan kemampuan pemecahan masalah yang dilakukan melalui proses menemukan dan interaksi mahasiswa dengan mahasiswa lainnya, mahasiswa dengan dosen suatu pemecahan masalah/latihan matematika. 
Kemampuan analitis matematis adalah kemampuan untuk menguraikan, meneliti dan menganalisis berbagai informasi yang digunakan untuk mengetahui suatu pengetahuan ilmu dengan menggunakan pikiran yang logis. Kemampuan analitis matematis merupakan suatu kemampuan berpikir tingkat tinggi yang harus dimiliki oleh siswa ataupun mahasiswa. Kemampuan analitis ini tidak bisa dicapai oleh mahasiswa jika mahasiswa belum menguasai aspek-aspek kognitif sebelumnya. Kemampuan analitis ini sangat komplek yang di dalamnya terdapat aspek pengetahuan, pemahaman dan aplikasi. Suherman dan Sukjaya mengungkapkan bahwa kemampuan analisis merupakan kemampuan untuk merinci atau menguraikan suatu masalah (soal yang diberikan) menjadi bagian-bagian yang lebih kecil serta dapat memahami hubungan dinatara bagian-bagiannya.

Kemampuan pemecahan masalah adalah suatu kemampuan kognitif yang menjadi salah satu tujuan dari pendidikan pendidikan sekolah. Kemampuan pemecahan masalah adalah suatu proses belajar individu untuk merespon dan mencari jalan ketika suatu jawaban dan langkah-langkah belum sempurna. Jadi kemampuan pemecahan masalah adalah kemampuan kognitif untuk mencari suatu penyelesaian atau jalan keluar sehingga menghasilkan suatu tujuan yang hendak dicapai. Indikator tahap kemampuan pemecahan masalah menurut Polya yang diadobsi dari penelitian-penelitian Setiawan, et. al. (2021), Nurhalin \& Ramlah (2021), Syadid \& Sutiarso (2021), Safi'i \& Bharata (2021) dalam penelitian ini, (1) memahami masalah; (2)membuat rencana pemecahan masalah; (3) menyelesaikan rencana pemecahan masalah; (4) memeriksa kembali hasilnya, lebih memungkinkan untuk tercapai dengan penerapan tutor sebaya.

Pandangan pemecahan masalah sebagai proses inti dan utama dalam kurikulum matematika, berarti pembelajaran pemecahan masalah lebih mengutamakan proses dan strategi yang dilakukan siswa dalam menyelesaikannya dari pada hanya sekedar hasil sehingga keterampilan proses dan strategi dalam memecahkan masalah tersebut menjadi kemampuan dasar dalam belajar matematika. Walaupun kemampuan pemecahan masalah merupakan kemampuan yang tidak mudah dicapai, akan tetapi oleh karena kepentingan dan kegunaannya maka kemampuan pemecahan masalah ini hendaknya diajarkan kepada peserta didik pada semua tingkatan.

Berdasarkan uraian di atas yang telah dijelaskan, adapun faktor lainnya yang menjadi penyebab kemampuan analitis matematis dan kemampuan pemecahan masalah mahasiswa lebih baik menggunakan model pembelajaran tutor sebaya dibandingkan menggunakan model pembelajaran konvensional karena mahasiswa yang mendapatkan model pembelajaran tutor sebaya setiap pembelajarannya peserta didik dilatih untuk aktif bertanya jika ada yang belum paham dengan cara lain seperti berdiskusi dan mengeluarkan pendapatnya. Ketika mahasiswa dapat mengikuti seluruh tahapan dengan baik, maka mahasiswa akan memahami dan menyelesaikan permasahan dengan baik.

\section{SIMPULAN}

Dari hasil penelitian dapat disimpulkan bahwa kemampuan analitis matematis dan pemecahan masalah pada pembelajaran matakuliah matematika analisis mahasiswa lebih tinggi daripada rata-rata kemampuan analitis matematis dan pemecahan masalah yang diberi model pembelajaran konvensional. Dengan demikian, model pembelajaran tutor sebaya berpengaruh positif terhadap kemampuan analitis matematis dan kemampuan pemecahan masalah pada mahasiwa kelas D semester 4 jurusan pendidikan matematika fakultas tarbiyah dan keguruan UIN Raden Intan Lampung.

Hasil penelitian mengenai penggunaan model pembelajaran tutor sebaya terhadap kemampuan analitis matematis mahasiswa jurusan pendidikan matematika UIN Raden Intan Lampung memberikan rekomendasi, diantaranya pendidik dalam mengajarkan materi matematika analisis kepada peserta didik, disarankan agar pendidik dapat menggunakan model pembelajaran yang memberikan pengalaman langsung kepada peserta didik untuk mencari dan menemukan sendiri konsep materi yang dipelajari serta bisa menjadikan peserta didik lebih aktif dan dapat mengeluarkan pendapatnya dan dapat terlibat dalam proses pembelajaran. Salah satunya yaitu menggunakan model 
pembelajaran tutor sebaya. Dengan melibatkan peserta didik aktif dalam proses pembelajaran, maka peserta didik akan lebih mudah memahami materi yang diberikan. Bagi penelitian selanjutnya yang meneraapkan model pembelajaran tutor sebaya disarankan untuk melihat peningkatan setiap indikator kemampuan analitis matematis dan kemampuan pemecahan masalah serta kemampuan-kemampuan yang lainnya. Semoga apa yang diteliti dapat memberikan manfaat serta sumbangan pemikiran baik pendidik pada umumnya dan peneliti pada khususnya.

\section{DAFTAR RUJUKAN}

Bloom, B. S. (1985). Developing talent in young children. New York: Bailantine.

Căprioară, D. (2015). Problem Solving - Purpose and Means of Learning Mathematics in School. Procedia - Social and Behavioral Sciences, 191, 1859-1864. https://doi.org/https://doi.org/10.1016/j.sbspro.2015.04.332

Desti, E., Anggoro, B. S., \& Suherman. (2018). Pengaruh Berpikir Kreatif Terhadap Kemampuan Memecahkan Masalah Matematika. Seminar Nasional Matematika Dan Pendidikan Matematika UIN Raden Intan Lampung, 1(2), 525-532.

Fajriah, N., \& Suseno, A. A. (2014). Kemampuan Siswa Sekolah Menengah Pertama dalam Menyelesaikan Masalah Matematika Berdasarkan Gaya Kognitif. EDU-MAT: Jurnal Pendidikan Matematika, 2(1), 15-21. https://ppjp.ulm.ac.id/journal/index.php/edumat/article/view/584/498

Fatma, M. (2016). Penggunaan Model Pembelajaran Group Investigation (GI) Untuk Peningkatan Kemampuan Berpikir Analitis Matematis Mahasiswa Pada Perkuliahan Analisis Riil. Jurnal Aksiomatik, 4(3), 1232-1241.

Ilma, R., Hamdani, A. S., \& Lailiyah, S. (2017). Profil Berpikir Analitis Masalah Aljabar Siswa Ditinjau dari Gaya Kognitif Visualizer dan Verbalizer. JRPM (Jurnal Review Pembelajaran Matematika), 2(1), 1-14. https://doi.org/10.15642/jrpm.2017.2.1.1-14

Iswara, E., \& Sundayana, R. (2021). Penerapan Model Pembelajaran Problem Posing dan Direct Instruction dalam Meningkatkan Kemampuan Pemecahan Masalah Matematis Siswa. Plusminus: Jurnal Pendidikan Matematika, 1(2), 223-234. https://journal.institutpendidikan.ac.id/index.php/plusminus/article/view/pv1n2_03

Krathwohl, D. R. (2002). A Revision of Bloom's Taxonomy: An Overview. Theory Into Practice, 41(4), 212-218. https://doi.org/10.1207/s15430421tip4104_2

Kusmaharti, D., \& Yustitia, V. (2020). Efektivitas Online Learning terhadap Kemampuan Pemecahan Masalah Matematika Mahasiswa. Journal of Medives : Journal of Mathematics Education IKIP Veteran Semarang, 4(2), 311-318. https://doi.org/10.31331/medivesveteran.v4i2.1199

Mulyatna, F., \& Nofiansyah, W. (2019). Error patterns in determining combined probability functions from continuous random variables. Journal of Physics: Conference Series, 1188(1). https://doi.org/10.1088/1742-6596/1188/1/012111

Nasution, M. D., \& Oktaviani, W. (2020). Pengembangan Perangkat Pembelajaran Berbasis Masalah untuk Meningkatkan Kemampuan Pemecahan Masalah Siswa SMP PAB 9 Klambir V T . P 2019/2020. Journal Mathematics Education Sigma (JMES), 1(1), 46-55. https://doi.org/http://dx.doi.org/10.30596\%2Fjmes.v1i1.4390

Nofitasari, L., Zaenuri, \& Mashuri. (2015). Keefektifan Model Pembelajaran Tutor Sebaya Bernuansa Etnomatematika Terhadap Kemampuan Pemecahan Masalah Peserta Didik pada Materi Segiempat. Unnes Journal of Mathematics Education.

Nurhalin, Y., \& Ramlah. (2021). Analisis Kemampuan Pemecahan Masalah Matematis Siswa Berdasarkan Disposisi Matematis. Maju: Jurnal Ilmiah Pendidikan Matematika, 8(2), 185-194. https://www.ejournal.stkipbbm.ac.id/index.php/mtk/article/view/716

Safi'i, A., \& Bharata, H. (2021). Hubungan Kemampuan Pemecahan Masalah dan Pemahaman Konsep Matematis terhadap Kemampuan Computer Self-Efficacy. JKPM (Jurnal Kajian 
Pendidikan Matematika), 6(2), 215-226. https://doi.org/10.30998/jkpm.v6i2.9826

Setiawan, E., Muhammad, G. M., \& Soeleman, M. (2021). Analisis Kemampuan Pemecahan Masalah Mahasiswa pada Mata Kuliah Teori Bilangan. Mosharafa: Jurnal Pendidikan Matematika, 10(1), 61-72. https://doi.org/10.31980/mosharafa.v10i1.735

Sudarman, S. W., \& Vahlia, I. (2016). Efektifitas Penggunaan Metode Pembelajaran Quantum Learning terhadap Kemampuan Pemahaman Konsep Matematis Mahasiswa. Al-Jabar: Jurnal Pendidikan Matematika, 7(2), 275-282. https://doi.org/https://doi.org/10.24042/ajpm.v7i2.42

Suherman, E., \& Sukjaya, Y. (1990). Petunjuk Praktis untuk Melaksanakan Evaluasi Pendidikan Matematika. Bandung: Wijayakusumah 157.

Syadid, R. A. A. C. I., \& Sutiarso, S. (2021). Hubungan Kemampuan Berpikir Reflektif Matematis dengan Kemampuan Pemecahan Masalah Matematis Peserta Didik. JKPM (Jurnal Kajian Pendidikan Matematika), 6(2), 327-336. https://doi.org/10.30998/jkpm.v6i2.9808

Yavuz, G., \& Erbay, H. N. (2015). The Analysis of Pre-service Teachers' Beliefs about Mathematical Problem Solving. Procedia - Social and Behavioral Sciences, 174, 2687-2692. https://doi.org/https://doi.org/10.1016/j.sbspro.2015.01.953

Zahrawati, F. (2020). Penerapan Model Problem Based Learning untuk Meningkatkan Hasil Belajar Sosiologi Siswa. Indonesian Journal of Teacher Education, 1(2), 71-79. https://journal.publication-center.com/index.php/ijte/article/view/93 
106 Nurmalasari, Anggoro, \& Andriani

JKPM (Jurnal Kajian Pendidikan Matematika) Vol.7, No.1 (2021) 